\title{
Determinants of Employee Job Satisfaction Police Commission of Dire Dawa Administration, Ethiopia
}

\author{
Biniyam Kebede Desta (MBA) M \& N Research \& Business Consultant Plc. (G. Manager) \\ Dire Dawa Ethiopia \\ Samson Meles Degefu (MBA) Regional Sales Manager (FMCG) Dire Dawa, Ethiopia
}

\begin{abstract}
The purpose of the study was to examine the determinants of police employee's job satisfaction in Dire Dawa Administration Police Commission. Cross - sectional survey quantitative designs adopted to collect the relevant data and information regarding the determinants of police employee's job satisfaction. The population of the study includes the permanent employees of Dire Dawa Administration Police Commission (DDAPC). In this study, both descriptive and inferential statistics data analysis was applied and data was analyzed with the help of Statistical Package for Social Sciences (SPSS) Software version 23.0 Program and STATA Software version 13. Descriptive statistics such as means and standard deviation and inferential statistics such as Ordinal Logistic Regression (O logit) model analysis was used to establish the determinants factors that affect employee's job satisfaction by the predictor variables. Among the major findings of the study, Working Condition and Job Enrichment practice are not statistically significant variables on determinants of police employee's job satisfaction. Based on this the top management of the DDAPC recommended to improve the working conditions and Job Enrichment practice. Preparing regular discussion meetings with employees' on some intervals is necessary to hear employees' request and to give appropriate response timely. This practice will contribute to improve the problem related with working conditions and Job Enrichment practice.
\end{abstract}

Keywords: Employee's job satisfaction and Dire Dawa Administration Police Commission

DOI: $10.7176 /$ EJBM/13-9-02

Publication date:May $31^{\text {st }} 2021$

\section{INTRODUCTION}

\subsection{Background of the Study}

Job satisfaction is one of the academic concepts that have received worldwide attention in the field of management and other areas recently. There are various definitions of job satisfaction as mentioned, first of all, it can be defined as concerning one's feeling or state of mind related with the work (Chughati \& Perveen, 2013) and "an employee's positive attitude towards the company, co-workers and, finally, the job" (Sypniewska, 2013). Job satisfaction is a very important aspect of an employee's well-being and has emotional, cognitive, and behavioral components (Saari \& Judge, 2004). According to Kaplan (2008), cited in Zaim, et al., (2012) emotional aspect refers one's feelings regarding the job, cognitive aspect refers one's thoughts and beliefs regarding the job, and, behavioral component refers to people's actions with respect to the job.

Employees that are satisfied with their job perform better and are less likely to be late or absent than those who are dissatisfied. Moreover employees, who are more productive and can stay longer on the job are said to have higher job satisfaction the implication is that, assessing employee job satisfaction of a given institution is very important to insure the success of that organization/ institution (Saiyadain, 2004, cited in Molla, 2015).

With regard to police work, which is usually conducted within the context of public sector organizations, job satisfaction is a serious issue as a result of the nature of its work. Clearly, a police force is a service-intensive organization with a significant proportion of its employees working in direct contact with publics. The Police Commission role in the community have typically focused upon the protection of life and property, crime prevention, the detection of offenders, and the preservation of peace and order. These roles encompass three main police functions: law enforcement (i.e., the use of power to control others); peace keeping (i.e., maintaining public safety); and service provision (i.e., assisting people requiring help. Police organizations require a high level of productivity and efficiency from those employees handling such dangerous situations. (Source: Dire Dawa Administration Police Commission HR annual report, 2019). Thus, it appears that there has been shortage of research over the topic under study in relation to, particularly employees like police force. In light of this, the study was a modest contribution to potential attempts made to fill this gap in the literature. Therefore, the primary objective of this study is to examine the determinants of police employee's job satisfaction in Dire Dawa Administration Police Commission.

\subsection{Statement of the Problem}

Lack of job satisfaction brings negative consequences like, job stress, poor overall morals, lack of productivity, high employee turnover, tardiness and high absenteeism (Singh \& Pandey, 2013).

Job satisfaction is an important precondition for the success of any organization. This is because satisfied 
employees are a crucial asset in any organization since they are likely be committed, loyal, accountable, and can work hard (Mathis \& John, 1999). Dissatisfied employees on the other hand, are the liabilities who are more likely to provide inferior services (Kaarna, 2007). Job satisfaction influences behaviour and performance of individual employees. Any organization cannot achieve its goals and targets unless its employees are satisfied with their jobs.

There are some academic works related to employees' job satisfaction in Ethiopia. However, most of them focused on sectors like education and health, among others. For example, studies by Mengistu (2012) and Gebremichael and Rao (2013) focused on employees' satisfaction in education sector while and Mengistu and Bali (2015) focused on health workers. Low job satisfaction was commonly observed in different public medical centers in Ethiopian hospitals due to lack of mentoring support in the work place. A study on Ethiopian anesthetists' job satisfaction level and factors affecting their level of job satisfaction indicate improper supervision problem to be one of the reasons for job dissatisfaction (Desalegn, 2015). Similarly a study in West Shoa zone indicated that the majority of respondents were dissatisfied with their job due to hospital bureaucratic management. Workers at public hospitals of West Shoa, Oromia regional sate shows that the mainstream of the respondents were not pleased with administration structure of their own hospitals ( Mengistu \& Bali, 2015). A study conducted in Jimma University specialized hospital, southwest Ethiopia, in 2009 among 127 health workers indicated that only $41.4 \%$ were satisfied with their job (Yami et al., 2011).

Another study conducted on "Assessment of job satisfaction among pharmacy professionals in south west of Ethiopia shows that poor salary and poor management might be the major factors for dissatisfaction and consequently migration of health professionals in Ethiopia" (Ahmed et al., 2013). Job satisfaction study in public sectors of health workers in Addis Ababa, Oromia, Amhara and Somali shows high level of dissatisfaction related with financial rewards (Hotchkiss et al, 2015).

A study on Job satisfaction study at Harari Region, Eastern Ethiopia shows laboratory professionals were highly satisfied when compared to other health worker. This may be related with better working environment like the availability of medical equipment and better working space (Geleto et al, 2015). A study from Jimma university specialized hospital describes employee dissatisfaction with their job observed due to lack of promotion, insufficient resources, supplies, poor infrastructure, and inadequate human power (Hotchkiss et al, 2015). Study on factors affecting Job Satisfaction in Mekelle University Academic Staff at Adi-Haqi campus shows that "The least motivating factor of respondents' jobs was the "salary. The findings show that those respondents were most satisfied with the content of their job and least satisfied with the context in which their job was performed (Hagos \& Abrha, 2015).

There are ample of evidences showing that Dire Dawa Administration Police Commission has faced problems with regard to employees' job satisfaction. As it is shown in the HR annual report (2015-2019) there was high turnover rate (Number of total employees that exit form Dire Dawa Administration Police Commission in last five years was 159 out of the total of 1,742, which was implies the turnover rate during the five years was $159(9.12 \%)$ and the actual total number of employees that exited from Dire Dawa Administration Police Commission. For instance it is facing employees' complaint regarding satisfaction related issues; especially the lower level position. They inform their dissatisfaction raise the issue during meetings. (Source: Dire Dawa Administration Police Commission HR annual report, 2019).

The researcher became interested to proof or disproof the Dire Dawa Administration Police Commission employee current job satisfaction. In Dire Dawa Administration Police Commission has not conducted a research on employee satisfaction. This problem seems significant and worth studying therefore initiated to address this problem.

While there is a vast growing body of empirical literature on job satisfaction in public and private organizations, however, determinants of employees' job satisfaction to the context had not yet been empirically explored using estimation models that determine employees' job satisfaction in Dire Dawa Administration Police Commission.

After reviewing the literature, the following factors were considered as factors affecting employee satisfaction, a set of ten specific factors of job satisfaction study variables were lack of research into the police force job satisfaction. Factors such as Salary and benefits, Promotion Opportunity, Supervisory relationship, Working condition, Relationship with co-worker, Training and Development, Recognition, Job enrichment, Perceived equity and Demographic variables like (Gender, Age, Education level, shift work and experience). These factors are not given adequate consideration; they may negatively affect job satisfaction of the police force were important issues that need to be considered.

Therefore, the researcher motivated to fill those aforementioned gaps and try to conduct a research/study. Thus, in the light of this the researcher decided to examine the determinants of job satisfaction among police forces in Dire Dawa Administration Police Commission brings to bear factors present in this organizations leading to employee dissatisfaction and there is a need for a better understanding of the issue of job satisfaction in police organizations. 


\subsection{Research Question}

1. Is there a significant job satisfaction difference among police employees of DDA Police Commission towards demographic variables like (Gender, Age, Education level, shift work and experience)?

2. What are the determinants of police employee's job satisfaction in Police Commission?

3. What are the bottlenecks of employee's job satisfaction in Dire Dawa Police commission?

\subsection{Objectives of the Study}

1. To examine the significant level of job satisfaction difference among police employees of DDA Police Commission towards demographic variables like (Gender, Age, Education level, shift work and experience).

2. To explore the determinants of police employee's job satisfaction in Police Commission.

3. To examine the bottlenecks of employee's job satisfaction in Dire Dawa Police commission.

\subsection{Research Hypothesis}

$\mathrm{H}_{1}$ : Adequate salary and benefits has significant influence on employee's job satisfaction.

$\mathrm{H}_{2}$ : Promotion Opportunity has significant influence on employee's job satisfaction.

$\mathrm{H}_{3}$ : Effective supervisory relationship has significant influence on motivation of employees.

$\mathrm{H}_{4}$ : Working condition has significant influence on employee's job satisfaction.

$\mathrm{H}_{5}$ : Relationship with co-worker has significant influence on employee's job satisfaction.

$\mathrm{H}_{6}$ : Training and Development has significant influence on employee's job satisfaction.

$\mathrm{H}_{7}$ : Recognition has significant influence on employee's job satisfaction.

$\mathrm{H}_{8}$ : Job enrichment has significant influence on employee's job satisfaction.

$\mathrm{H}_{9}$ : Perceived equity has significant influence on employee's job satisfaction.

$\mathrm{H}_{10}$ : Employee job satisfaction and Socio-demographic factors (Gender, Age, Education level, shift work and experience) have significant association.

\section{RESEARCH METHODOLOGY}

This study has been conducted in Dire Dawa Administration Police Commission. Cross - sectional survey quantitative designs adopted to collect the relevant data and information regarding the determinants of police employee's job satisfaction. This study was employed both primary and secondary sources of data collection. The population of the study includes the permanent employees of Dire Dawa Administration Police Commission. There are a total of 1,724 population members out of which 183 are managerial employees and the rest 1,559 are non-managerial employees. The researcher was used, a Multi-stage sampling technique. In this case, we have a two-stage sampling technique process consisting of stratified and simple random sampling technique was used to draw the sample elements. In the research took total sample size was 1,742 employees of Dire Dawa Administration Police Commission and the sample size is 324 at $95 \%$ confidence level. The questionnaires were self-administered by respondents. The questionnaire was the Minnesota Satisfaction Questionnaire (MSQ) is designed to measure specific aspects of an employee's satisfaction with his or her job. In this study, both descriptive and inferential statistics data analysis was applied. Descriptive statistics such as means and standard deviation and inferential statistics such as independent-samples t-test and Ordinal Logistic Regression (O logit) model analysis was used to establish the determinants factors that affect employee's job satisfaction by the predictor variables. Data was analyzed with the help of Statistical Package for Social Sciences (SPSS) Software version 23.0 Program and STATA Software version 13 to help generate statistical analysis and present the data through the statistical techniques was presented in tables. The questionnaires were distributed and collected within one month (from July 14, 2020 to August 17, 2020). A total 324 questionnaires were distributed to the employees of DDAPC. From the total number of collected questionnaires were returned fully completed, giving a response rate of $247(76.23 \%)$ whereas $77(23.76 \%)$ were not responded and incomplete questionnaires.

\section{Ordinal Logistic Regression (O logit) Model Analysis}

Ordinal Logistic Regression (OLR) model was used. Ordinal logistic regression is a generalized linear modeling technique that may be used to model a single response variable which has been recorded on at least an interval (ordinal) scale. The model is represented by (Gujarati, 2004) as the following function. Generally, we can express the ordinal logistic model for $\mathrm{k}$ predictors with $\mathrm{P}-1$ levels response variable as:

$$
\frac{\ln (\Sigma \operatorname{pr}(\mathbf{Y} \leq \mathbf{j} \mid \mathbf{x})}{1-\Sigma \operatorname{pr}(\mathbf{Y} \leq \mathbf{j} \mid \mathbf{x}))}=\boldsymbol{\alpha} \mathbf{j}+\boldsymbol{\beta} \mathbf{i}, \mathbf{1}
$$

$\log [p(y \leq j / x)] \alpha+\beta_{1} x_{1}+\beta_{2} x_{2}+\beta_{3} x_{3}+\beta_{4} x_{4}+\ldots \ldots \ldots \ldots \ldots \varepsilon$

$\boldsymbol{L o g}$ Job satisfaction $\left.*_{i}\right)=\boldsymbol{\alpha} \boldsymbol{j}+\boldsymbol{\beta}_{1}$ Salary and benefits $*_{i}+\boldsymbol{\beta}_{2}$ Promotion Opportunity $*_{i}+\boldsymbol{\beta}_{3}$ Supervisory relationship $*_{i}$ $+\boldsymbol{\beta}_{4}$ Working condition $* i+\boldsymbol{\beta}_{5}$ Relationship with co-worker ${ }^{*} i+\boldsymbol{\beta}_{6}$ Training and Development ${ }^{*} i+\boldsymbol{\beta} 7$ Recognition ${ }^{*} i+$ $\boldsymbol{\beta}_{\boldsymbol{s}}$ Job enrichment ${ }^{*} i+\boldsymbol{\beta}_{9}$ Perceived equity ${ }^{*} i+\boldsymbol{\beta}_{10}$ Demography $* i+\boldsymbol{\varepsilon} * i$ 
Where: $\boldsymbol{\alpha} \mathbf{j}=$ represents Constant term

$\mathbf{i}=$ represent each respondent whose response was used for analysis

$\boldsymbol{\beta} \mathbf{j}=(\mathbf{j}=1,2,3, \ldots 13)$ are logistic regression coefficients to be estimated and,

$\mathbf{\varepsilon i}=$ random errors which are assumed to be independent.

\subsection{Reliability of Statistics}

Table 1 Overall Reliability Statistics

\begin{tabular}{ccc}
\hline Cronbach's Alpha & Cronbach's Alpha Based on Standardized Items & N of Items \\
\hline .738 & .778 & 9 \\
\hline
\end{tabular}

Source: Survey Result (2020)

From Table 1above, the overall reliability coefficient of the questionnaire was 0.778 and generally, all 9 items in the questionnaire were reliable. Based on the Cronbach's Alpha value of the measurement under this study proved to be good and from this, we can conclude that the instrument's internal consistency for the study is $77.8 \%$. Therefore, the expected scales used in this study demonstrate high reliability.

\section{RESULTS AND DISCUSSIONS}

3.1 Descriptive Statistics on Job Satisfaction Survey

The summary of descriptive statistics of all variables that are evaluated based on a 5-point Likert scale ("1" being "strongly disagreed" to " 5 " being "strongly agreed").

Table 2 Descriptive Statistics of overall job satisfaction

\begin{tabular}{|c|c|c|c|c|c|}
\hline Varibles & $\mathbf{N}$ & Minimum & Maximum & Mean & Std. Deviation \\
\hline Salary and Benefit & 247 & 2.83 & 3.67 & 3.3347 & .19651 \\
\hline Working Condition & 247 & 2.25 & 3.00 & 2.7702 & .19805 \\
\hline Recognition & 247 & 3.00 & 4.17 & 3.5958 & .31277 \\
\hline Supervision & 247 & 2.57 & 4.43 & 3.4268 & .55336 \\
\hline Promotion & 247 & 3.00 & 4.17 & 3.3941 & .31473 \\
\hline Training and Development & 247 & 2.60 & 4.00 & 3.3951 & .35150 \\
\hline Relationship with co-worker & 247 & 3.00 & 3.83 & 3.4487 & .20786 \\
\hline Perceived equity & 247 & 1.00 & 4.75 & 3.7500 & 1.06449 \\
\hline Job Enrichment & 247 & 1.75 & 3.04 & 2.6392 & .23691 \\
\hline Job Satisfaction & 247 & 2.10 & 3.04 & 2.6392 & .23691 \\
\hline Valid N (list wise) & 247 & & & & \\
\hline
\end{tabular}

\section{Source: Field survey, 2020}

The findings in table 2 above demonstrate the aggregate mean and standard deviation score values have been calculated, Relationship with Co-worker, Equity/Fairness, Recognition for good work and supervisor relationship were good aggregate mean and standard deviation (3.45 and 0.208), (3.75 and 1.064), (3.68 and 0.313) and (3.43 and 0.553 ) respectively.

The salary and benefits, working condition, promotion opportunities, Training and Development,

Job-Enrichment and Employee's job satisfaction were presented the mean and standard deviation score values have been calculated, average satisfaction level of aggregate mean and standard deviation (3.33 and 0.197), (2.77 and 0.198$)$, (3.39 and 0.315), (3.39 and 0.352), (2.639 and 0.236) and (2.639 and 0.236) respectively.

\subsection{Ordered Logit Regression model summary}

\section{Table 3 Logit Result for Determinants of Job Satisfaction}

$$
\begin{aligned}
& \text { Ordered logistic regression } \quad \text { Number of Obs }=\quad 247 \\
& \text { LR chi2 (14) }=379.61 \\
& \text { Prob }>\text { chi } 2=0.0000 \\
& \text { Log likelihood }=-102.16454 \quad \text { Pseudo R2 }=0.6501
\end{aligned}
$$

Source: The Researcher's Survey 2020

From the above result we can understand that pseudo $\mathrm{R}^{2}$ of 65.01 percent implies that it is good enough in qualitative response models such as Ordered Logit. Pseudo R-square has maximum value shows that $65.01 \%$ of the variation in determinants of job satisfaction was explained by the independent (or predictor) variables in this model.

Before running the ordered logistic regression (O logit regression) analysis, all the hypothesized explanatory variables were checked for the fitness and adequacy of the model, and consequently found to be significantly adequate and fitted well. As indicated in table 3 above, the overall significance and fitness of the $\mathrm{O}$ logit regression model is determined by its chi-square value. The chi-square value is Prob $=0.0000$; hence the explanatory variables can significantly predict the dependent variable. 
Table 4 The Marginal Effects of the Ordered Logit Model for Determinants of Employee's Job Satisfaction

\begin{tabular}{lccrrrr}
\hline & & & \multicolumn{4}{c}{ Employee's Job Satisfaction } \\
\cline { 5 - 7 } Variables & Coefficients & $\mathbf{P}>|\mathbf{Z}|$ & Low & Moderate & High & Very High \\
\hline Age & 4.034336 & 0.000 & .0193144 & .0374362 & .010216 & .001013 \\
Gender & .3647363 & 0.654 & .0172566 & .0334476 & .0091276 & .000905 \\
Service years & 2.117448 & 0.000 & .0070879 & .0137381 & .003749 & .0003717 \\
Education & 2.925079 & 0.000 & .0151416 & .0293482 & .0080089 & .0007941 \\
Shift work & 1.176976 & 0.191 & .0012366 & .0023969 & .0006541 & .0000649 \\
Salary and Benefit & .7087546 & 0.018 & .018855 & .0365458 & .009973 & .0009889 \\
Working Condition & .7954231 & 0.570 & .0165074 & .0319954 & .0087313 & .0008657 \\
Recognition & .7017782 & 0.055 & .0178389 & .0345762 & .0094355 & .0009356 \\
Supervisory Relationship & .5083629 & 0.000 & .0049241 & .0095441 & .0026045 & .0002582 \\
Promotion & 2.737126 & 0.001 & .0256669 & .0497489 & .013576 & .0013461 \\
Training and Development & .4762099 & 0.032 & .0224314 & .0434778 & .0118647 & .0011764 \\
Coworker Relationship & .1009161 & 0.004 & .0361458 & .0700597 & .0191187 & .0018957 \\
Equity & 2.925079 & 0.000 & .0165445 & .0320675 & .0087509 & .0008677 \\
Job Enrichment & .3647363 & 0.654 & .0172566 & .0334476 & .0091276 & .000905 \\
\hline
\end{tabular}

\section{Source: The Researcher's Survey 2020}

In table 4 above the ordered logit regression model was also fitted to estimate the effects of a unit change in the individual hypothesized explanatory variable towards the variance of determinants of police employee's job satisfaction in Dire Dawa Administration Police Commission. The results showed that police employee's job satisfaction had a significant association with Age, Experience (Service Years), Education, Salary and Benefit, Recognition, Supervisory Relationship, Promotion, Training \& Development, Coworker Relationship and Equity at 5\% level of significance. Whereas Gender, Shift Work, Working Condition and Job Enrichment are not statistically significant explanatory variables on determinants of police employee's job satisfaction at $5 \%$ level of significance.

\subsubsection{Demographic factors}

The study results reported in 4 above that age positively determinants of police employee's job satisfaction level at $5 \%$ significant level. Its marginal effect exhibited that a one unit (year) increase in the age of police employee's, given that all of the other variables in the model are held constant, would result in a probability of increase in low, moderate, high and very high job satisfaction level categories by about $1.9 \%, 3.7 \%, 1 \%$ and $0.1 \%$ respectively.

Service years of police employee's positively determinants of police employee's job satisfaction level at 5\% significant level. Its marginal effect exhibited that a one unit (service year) increase in the age of police employee's, given that all of the other variables in the model are held constant, would result in a probability of increase in low, moderate, high and very high job satisfaction level categories by about $0.7 \%, 1.3 \%, 0.3 \%$ and $0.03 \%$ respectively.

Education levels of police employee's positively determinants of police employee's job satisfaction level at $5 \%$ significant level. Its marginal effect exhibited that a one unit (service year) increase in the age of police employee's, given that all of the other variables in the model are held constant, would result in a probability of increase in low, moderate, high and very high job satisfaction level categories by about $1.5 \%, 2.9 \%, 0.8 \%$ and $0.079 \%$ respectively.

Another factor Gender and Shift Work positively determinants of police employee's job satisfaction and are not statistically significant at 5\% level of significant.

Years of experience refers to the time or number of years an employee has spent working for a specific organisation. Employees' levels of job satisfaction would then increase after a number of years of service.

As discussed with regards to the age factor, the years of experience factor was found to have a positive relationship with job satisfaction in some studies. For example, Ronen (1978) highlighted that employees' expectations are high at the time of appointment, but when these expectations are not met, the resultant effect leads to a drop in job satisfaction. As employees become more mature and experienced, their expectations will be more attainable, which results in increased job satisfaction. Indeed, there are other work demographic factors that influence job satisfaction such as shift work. However, not many studies have sought to investigate these issues.

\subsubsection{Salary \& benefit}

The variance of determinants of police employee's job satisfaction in Dire Dawa Administration Police Commission was found to be influenced positively by the availability of adequate salary and benefits at $5 \%$ level of significance. The marginal effect showed that, an increase of one unit of adequate salary and benefits of police employee's, other variables being constant, would increase the probability of their job satisfaction level for low, moderate, high and very high job satisfaction level categories by about $1.8 \%, 3.6 \%, 0.9 \%$ and $0.09 \%$ respectively, other things being constant. 
The finding is consistent with previous studies which found salary and incentives to be an important positive determinant of job satisfaction (for example, Seo et al., 2004; Ellickson and Logsdon, 2001; Karatepe et al., 2003; Ting, 1997). Al-Fadley (1996), in his research among 269 police officers in the Cairo Police Force, found a significant association between salary and fringe benefits and overall levels of job satisfaction.

\subsubsection{Working Condition}

Availability of favorable working condition was deemed to be an important element to improve police employee's job satisfaction. Working condition in the study area was found to have positive and $(0.57)>5 \%$ level insignificant effect on police employee's job satisfaction are not statistically significant at $5 \%$ level of confidence. The marginal effect on the availability of favorable working condition implies, given that other variables in the model are held constant, that a unit increase in favorable working environment would increase the probability of job satisfaction for low, moderate, high and very high job satisfaction level categories by about $1.6 \%, 3.1 \%, 0.87 \%$ and $0.087 \%$ respectively, other things being constant.

In consonance with the field survey, Gyekye (2005) confirms that job satisfaction has a positive link with safety. Organisations with good safety policies do not only reduce operational cost but protect life and reduce accident level as well. Working conditions consists of the physical and social conditions at the work. People want to work in a comfortable, safe environment, a clean, modern and enough-equipped environment (Sun, 2002) and work in good conditions such as appropriate temperature, lighting and noise (Green, 2000). Workplace safety is a key issue for employers and employees. Everyone has a responsibility to ensure the safety of him or her and others affected by their work activities in the workplace.

\subsubsection{Recognition}

Recognition encompasses several ways to recognize employees job satisfaction such as greeting for better jobs, attach thanks to their paycheck, acknowledge employee milestones, appreciation for coming up with new ideas, holding celebrations for success, arranging frequent contests and other team building activities, etc. The model results revealed that recognition was assessed to have a positive and significant influence on employee's job satisfaction at 5\% level. Holding all other variables in the were model constant, as recognition of employees in DDAPC increases, the probability of their job satisfaction of low, moderate, high and very high level of job satisfaction categories by about $1.7 \%, 3.4 \%, 0.94 \%$ and $0.09 \%$ respectively.

Therefore, recognition is one of the most powerful methods of rewarding people. Recognition is the acknowledgement of an individual or team's behavior, effort and accomplishments that support the organization's goals and values. Recognition can be provided by positive and immediate feedback from managers and colleagues that acknowledge individuals and team contributions. It is also provided by managers who listen to and act up on the suggestion of their team's members. Other actions that provide recognition include acknowledge contribution, allocation to a high-profile project, and enlargement of the job to provide scope for more interesting and rewarding work (Tezera, 2006).

\subsubsection{Relationship with supervisors}

Another determinants factor of police employee's job satisfaction in Dire Dawa Administration Police Commission was the Supervisory Relationship, which has a positive and significant effect on employee's job satisfaction at $5 \%$ level of confidence The estimated coefficient of the variable suggested that, being other variables in the model kept constant, a one unit increase in the Supervisory Relationship the probability of employee's job satisfaction for low, moderate, high and very high job satisfaction level categories by $0.49 \%, 0.95 \%, 0.26 \%$ and $0.025 \%$ respectively, other things being constant.

Many research findings from Western countries have reported a positive association between supervision and job satisfaction (e.g. Ting, 1997; Seo et al., 2004; Bennett, 1997). Employee job satisfaction have positively affected by supervisors' support and recognition of employees (Yang, et al., 2011). Since the supervisors are representative for the institution, if they are supportive and helpful, employees perceive the organization as the same (Emhan, et al., 2014). Communication between supervisors and subordinates determines employees' attitudes towards their jobs. In addition, management style of supervisors is important and it can be different. For example, Vroom (1964) maintains that the supervisor who is competent, democratic, considerate to his subordinates, and has a good relationship with his employees will cause the workers to have positive feeling towards their jobs. However, when relations, trust and communication with the supervisors are poor, employees may feel stressed with this relationship and this may eventually lead to dissatisfaction (Wech, 2002).

\subsubsection{Promotion Opportunities}

Promotion is another factor determining police employee's job satisfaction in Dire Dawa Administration Police Commission; the results reported that there was a positive and significant effect of promotion on employee's job satisfaction at 5\% level of confidence. As the effect of a one unit of promotion increases, the probability of employee's job satisfaction for low, moderate, high and very high job satisfaction level categories by $2.5 \%, 4.9 \%$, $1.3 \%$ and $0.1 \%$ respectively, other things being constant.

The advancement of an employee from one job position to another job position that has a higher salary range, a higher title together with higher job responsibilities was revealed as a determinant. The finding falls in line with 
Teseema and Soeters's (2006) position in their research study that higher level of job satisfaction and better performance of employees is attached to good promotional practices. The finding of this study is parallel with those from previous Western studies which found promotional opportunities to be positively related to job satisfaction (for example, Ting, 1997; Fosam et al., 1998; Ellickson and Logsdon, 2001).

\subsubsection{Training and development}

The availability of training and development, which describes the formal, ongoing efforts that are made within DDAPC to improve the performance and self-fulfillment of their employees through a variety of training programs, is another determinant factor of employee's job satisfaction having a positive and significant influence on employee's job satisfaction at 5\% confidence level. The results of marginal effect indicate that, keeping other variables constant, an increase of the availability of training and development in DDAPC would increase the probability of employee's job satisfaction of low moderate, high, and very high categories increase by $2.2 \%, 4.3 \%$ and $1.18 \%$ and $0.11 \%$ respectively. The finding is quite consistent with Siebern (2005) who found out in his study that job satisfaction is higher in organisation where there is access to training. Workers want to improve their skills, abilities, knowledge, and to learn new things especially, which provide personal growth. In parallel with, if they are satisfied on self-improvement opportunities, their overall job satisfaction level increases. Therefore, job training plays a key role for personal development opportunities and helps employees to be more specific with their job, as a result, employee job satisfaction increases. In addition, employee development programs improve workers' satisfaction level by giving them more sense of confidence, providing to control over their career and increasing positive feelings towards their job (Jin \& Lee, 2012).

\subsubsection{Relationship with co-workers}

Employee's job satisfaction respond was found to be influenced positively and significantly by coworker's relationship, which is friendly, warm and cooperative relationships among workers, at $5 \%$ level of significance. Given that all other variables in the model kept constant, the marginal effect showed that, as employee's relationship with coworkers in DDAPC in the study area increases, the probability of employee's job satisfaction for low moderate, high, and very high categories increase by $3.6 \%, 7.0 \%$ and $1.9 \%$ and $0.18 \%$ respectively.

Consistent with the literature, this study has confirmed a significant positive association between coworker's relationship and employee's job satisfaction. Schermerhorn et al., (2005) who posit that promotion; pay and relationship with co-workers are the major factors that influence employee attitude towards work. Employees that have a better relationship with their coworkers are more likely to be satisfied with their job (Yang, et al., 2011). According to Locke, employees prefer to work with people being friendly, supportive, and cooperative (Başar, 2011). Since people spend majority of their times with colleagues, if co-workers make them happy, this has positive impact on their job satisfaction (Beşiktas, 2009). The findings reflect the importance of social relations in the workplace on employee job satisfaction. Maslow (1970) considers this issue to be one of a third category called social needs. In this category, Maslow refers to the need for belonging and love that employees require in order to be fulfilled; this draws attention to the importance of interpersonal relationships and socialization in overall job satisfaction.

\subsubsection{Equity/Fairness}

Regarding equity or fairness in Dire Dawa Administration Police Commission, the model results exposed that equity was estimated to have a positive and significantly influence on employee's job satisfaction at $5 \%$ level of confidence. The effect of a unit increase in equity, other variables held constant, the probability of the employee's job satisfaction for low moderate, high, and very high categories increase by $1.6 \%, 3.2 \%$ and $0.8 \%$ and $0.08 \%$ respectively. The findings of this study correspond with those outcomes reported in the literature with respect to a positive and significantly influence on employee's job satisfaction. Indeed, employees usually tend to compare themselves with employees who have similar qualifications, and who have served a similar number of years in the organisation. An employee who assumes he/she got fair pay (not absolute amount of pay but thinking) will be satisfied in his/her job and the reverse is true (Singh \& Pandey 2013; Saiyadain 1985).

Fairness and equal treatment have a great impact on increasing job satisfaction. Consequently, if pay or benefits are used to motivate workers or have any positive influence, it should be felt to be fair and equitable. Janssen (2001) states that there is not much research examining the influence of perceptions about workplace fairness, and other workplace variables, and the resulting impact on job outcomes. Furthermore, issues related to fairness and equity within the organisation was found to be important. For instance, organisations, when dealing with provisions such as salary and rewards, should keep in mind that individuals often compare their job inputoutput relative to those of others inside the organisation. Handy (1993) indicates that a high level of pay is not often an issue in many cases, but fair and equitable levels which are based on a comparison made by workers is. As Adam's (1963) equity theory suggests, satisfaction is the result of social comparison with respect to relevant referents. Promotion opportunities should be characterized by fairness and equity which are important to any employee in any organisation.

\subsubsection{Job-Enrichment}

The last determining factor of police employee's job satisfaction in Dire Dawa Administration Police Commission 
was job enrichment, which is a job redesign technique that allows employees to have autonomy on how they perform their own tasks and giving them more responsibility. The result also showed that job enrichment has positive and $(0.654)>5 \%$ level insignificant effect on police employee's job satisfaction are not statistically significant at 5\% level of confidence. The marginal effect indicated that, given that other variables in the model held constant, an increase of a unit of job enrichment in DDAPC the probability of employee's job satisfaction of low moderate, high, and very high categories increase by $1.7 \%, 3.3 \%$ and $0.9 \%$ and $0.09 \%$ respectively. The findings of this study correspond with Shipton et al., (2004) maintain that employees are most likely to contribute their knowledge and skills in order to innovate, in situations where they feel positively towards their jobs and their organisations. The job enrichment technique suggested by Herzberg (1966) increases levels of employee satisfaction by increasing individuals' responsibilities, authority and freedom, as well as reducing the amount of supervision to which individuals are subjected, and introducing more challenging and exacting tasks.

\section{RECOMMENDATIONS}

On the basis of the major findings drawn the following recommendations are offered as possible solutions for the existing challenges found in Dire Dawa Administration Police Commission.

* The DDAPC management is required to influence policy makers and Ethiopia Federal Police Commission in order to make up-to-date market assessment for paying fair salary and benefit that fit with current living situation and also to improve different payment for related work. DDAPC management needs to show for policy makers the current employee's dissatisfaction rate and its implication regarding their salary and benefit. Salary and benefit need to accommodate the current living situation.

* With respect to the current training and development process, the DDAPC's HRM and managers need to timely assess their training development opportunity and its fairness. To address the current gap it is necessary to redesign the current training and development process. It needs to insure the fairness of the process for employees' selection for training and development opportunity, clarity of the process and application of the core values of the organization during the selection time. More work is expected to improve the negative impression of employees in terms of fairness and to create clarity in the process. It needs to follow good governance principles strictly and aware the employees about the training and development criteria and process very well.

4 DDAPC which provide employees with the opportunities to work on different tasks, as a part of their orientation programme, enable those employees to learn the importance of their work and how it affects the work of their colleagues in the organisation. This may help in exploring the issue of which departments/tasks can best utilize their own skills. For example, job rotation is of great help for newcomers, as it introduces them to the different functions of the organisation within which they are working. Utilizing job redesign strategies such as job rotation and enrichment could be successful approaches to make jobs more interesting. This can help police managers to be mindful of workers' preferences, competencies and interests.

\& This finding suggests that the DDAPC employees pay a great deal of attention to promotion, which significantly affects their job satisfaction.

* With respect to the current practice in employee safety and health, the Dire Dawa Administration Police Commission is required to assess the dissatisfaction reasons regularly and take appropriate actions timely. DDAPC need to see negative effects of employee job safety and health regularly and proactively. Continuous assessment and improvement is required to maintain work force and to increase their satisfaction. It also needs to improve delay in materials delivery and follow safety guides strictly.

$\$$ Among the other major findings of the study, Working Condition and Job Enrichment practice are not statistically significant variables on determinants of police employee's job satisfaction. Based on this the top management of the DDAPC recommended to improve the working conditions and Job Enrichment practice. Preparing regular discussion meetings with employees' on some intervals is necessary to hear employees' request and to give appropriate response timely. This practice will contribute to improve the problem related with working conditions and Job Enrichment practice.

\section{Area for further research}

This study has focused on the determinants of police employee's job satisfaction in Dire Dawa Administration Police Commission. The study has touched different aspects on employee's job satisfaction level is explained by predictors such as promotion opportunity, supervision relationship, salary \& benefit, working condition, relationship with co-worker, training \& development, recognition, job enrichment, perceived equity and demographic factors. The study also recommends that future researchers will study needed to be under taken to examine employee's job satisfaction in other privet and public service organizations with larger samples and other additional variables. 


\section{REFERENCES}

Adams, J. S. (1963) Inequity of social exchanges advances in experimental social psychology. New York: Academic Press.

Ahmed S.M, Tolera M \& Angamo M.T (2013) Assessment of job satisfaction among Pharmacy professionals in Southwest Ethiopia International Journal of Pharmacy Science Res; 4(6); 2351-2358 doi: 10.13040/IJPSR.0975-8232.4(6).2351-58

Al-Fadley, M. (1996), "Factors determining the level of job satisfaction in police work: A case study of the police force in Cairo", Ph.D Thesis, University of Exeter.

Başar, U. (2011). ÖrgütselAdaletA lgısı, Örgütsel Özdeşleşmeveİş Tatmini Arasındakiïlişkilere YönelikGörgül BirAraştırma.

Bennett, R.R. (1997), "Job satisfaction among police constables: a comparative study in three developing nations", Justice Quarterly, 14 (2), 295-323.

Chughati, F. D., \&Perveen, U. (2013) A Study of Teachers Workload and Job Satisfaction in Public And Private Schools At Secondary Level in Lahore City Pakistan, 2(1), 202-214.

Desalegn. N. (2015) Ethiopian Anesthetists Job Satisfaction Level and Factors Affecting Their Level of Job Satisfaction Journal of Anesthesiology Vol. 3, No. 5, 2015, pp. 17-24. doi: 10.11648/j.ja.20150305.11

Dire Dawa Administration Police Commission HR annual report, 2019

Ellickson, M. \& Logsdon, K. (2001), "Determinants of job satisfaction of municipal government employees", State Local Government Review, 33 (3), 173-84.

Emhan, A., Mengenci, C., Taşdöven, H., \& Garayev, V. (2014).Yapısal Eşitlik Modeli Kullanılarak İş Memnuniyeti, YöneticiDesteğiveTükenmişlikKavramlarıArasındakiİlişkilerinAnalizi: Bankacılık SektöründeBir Uygulama. The Journal of Social and Economic Research, 14(27), 75-96.

Fosam, E. B., Grimsley, M. F. J. \& Wisher, S. J. (1998), "Exploring models for employee satisfaction with particular reference to a police force", Total Quality Management, 9, (2/3), 235-247.

Gebremichael, H. \& Rao, B. V. P. (2013) Job satisfaction and organizational commitment between academic staff and supporting staff (wolaita sodo university -Ethiopia as a case) Far East Journal of Psychology and Business, 11, 11-32.

Geleto A., Baraki N., Atomsa G. E. \& Dessie Y. (2015) Job satisfaction and associated factor among health care providers at public health institutions in Harari region, eastern Ethiopia: a cross-sectional study. Retrieved from: www.biomedcentral.com/submit

Green, J. (2000) Job Satisfaction of Community College Chairpersons Virginia Polytechnic Institute and State University.

Gujarati, D.N (2004) Basic econometric, 4th International ed. McGraw Hill New York, USA

Gyekye, S. A. (2005), Workers' Perceptions of Workplace Safety and Job satisfaction. International Journal of Occupational Safety and Ergonomics (JOSE), Vol. 11(.3), p. 291-302

Hagos. G. and Abrha K. (2015) Factors affecting Job Satisfaction in Mekelle University Academic Staff at AdiHaqi campus International Journal of Scientific and Research Publications, Volume 5, Issue 1, ISSN 22503153 Retrieved from http://www.ijsrp.org

Hertzberg, F. (1966) Motivation-hygiene profiles: Pinpointing what ails the organization, Organization Dynamics, Vol 3(2), 18-29

Hotchkiss D.R, Hailom Banteyerga and Manisha Tharaney (2015) Job satisfaction and motivation among public sector health workers: evidence from Ethiopia Human Resources for Health (2015) 13:83 DOI $10.1186 / \mathrm{s} 12960-015-0083-6$

Jin, M. H., \& Lee, M. Y. (2012) The Effects of Autonomy, Experience, and Person-Organization Fit on Job Satisfaction : The Case of Public Sector. The International Journal of Social Sciences, 6(1), 18-44.

Kaarna, M. (2007) The importance of job satisfaction in hospital quality process unpublished Partial Fulfillment of the Requirement for the Award of Master Degree thesis, Nordic school of public health.

Maslow, A. H. (1970). Motivation and Personality (2nd ed.). New York: Harper and Row.

Mathis, R., \& John, H. (1999) Changing nature of human resource management Jackson Publisher: South-Western Educational Publishing.

Mengistu Darge (2005) Job Satisfaction of Employees in Oromia Educational and Capacity Building Bureau and Its Zonal Offices Unpublished MA Thesis, Addis Ababa University. Addis Ababa, Ethiopia.

Mengistu, G. K. (2012) Job Satisfaction of Secondary School Teachers in Ethiopia PhD, University of South Africa.

Mengistu M.M and Bali A.G (2015) Factors Associated to Job Satisfaction Among Healthcare Workers at Public Hospitals of West Shoa Zone, Oromia Regional State, Ethiopia: A Cross Sectional Study Science Journal of Public Health. Vol. 3, No. 2, 2015, pp. 161-167.doi: 10.11648/j. sjph. 20150302.12

Molla (2015) Ensuring Job Satisfaction for Managing People at Work: Global Disclosure of Economics and Business, Volume 4, No 2/201, retrieved from journal URL

Ronen, S. (1978) "Job satisfaction and the neglected variable of job seniority", Human Relations, 31 (4), 297-308 
Saari, L. M., \& Judge, T. a. (2004) Employee Attitudes and Job Satisfaction Human Resource Management, 43(4), 395-407. doi:10.1002/hrm.20032

Saiyadain, M.S. (1985), "Personal characteristics and job satisfaction: India-Nigeria comparison", International Journal of Psychology, 20, 143-53.

Schermerhorn, J., Hunt, J. and Osborn, R. (2005), Organizational behaviour, Ninth Edition, John Willey \& Sons, Inc

Seo, Y., Ko, J. \& \& Price, J.L. 2004, "Determinants of Job satisfaction among hospital nurses: a model estimation in korea", International journal of Nursing studies, vol. 41, pp. 437-466.

Shipton, H., West, M., Parkes, C. \& Dawson, J. (2004), “Aggregate job satisfaction, HRM and organisational innovation", Working Paper RP0429, Aston University

Siebern-Thomas, F. (2005), “Job quality in European labour markets”, In Bazen S., Lucifora C. and Salverda W. (Eds.), Job Quality and Employer Behaviour, Palgrave Macmillan, Basingstoke, Hants, 31-66.

Singh, Y. and Pandey, M. (2013) Organizational behavior India: Aitbs publishers

Sun,H.Ö.(2002). İş DoyumuÜzerine Bir Araştırma: TürkiyeCumhuriyeti Merkez Bankası Banknot Matbaası GenelMüdürlüğü. Ankara.

Sypniewska, B. A. (2013) Evaluation of Factors Influencing Job Satisfaction.VizjaPress\&IT.57-71.doi: 10.5709/ce.1897-9254.131.

Tessema, M., Soeters, J.(2006), Challenges and prospects of HRM in developing countries:. Testing the HRMperformance link in Eritrean civil service International Journal of Human Resource Management, 17(1): 86105

Tezera Misganaw (2006), the relationship of reward management practices to employees ${ }^{\text {ee }}$ job satisfaction in Ethiopian Insurance Corporation, master's thesis Addis Ababa University

Ting, Y. 1997, "Determinants of job satisfaction of federal government employees", Public Personnel Management, vol. 26, no. 3, pp. 313

Vroom, V. H. (1964) Work and Motivation New York: John Wiley \& Sons, Inc

Wech, B.A. (2002), "Trust context: effect on organizational citizenship behavior, supervisory fairness, and job satisfaction beyond the influence of leader-member exchange", Business and Society, 41 (3), 353-60.

Yami A, Hamza L et al. (2011) Job satisfaction and its determinants among health workers in Jimma University specialized hospital, southwest Ethiopia. Ethiop J Health Sci. 2011; 21(special issue):19-27.

Yang, S. B., Brown G. C., \& Moon, B. (2011) Factors Leading to Corrections Officers' Job Satisfaction. Public Personnel Management, 40(4), 359-369.

Zaim, H., Kurt, I., \&Tetik, S. (2012). Casual Analysis of Employee Satisfaction and Performance: A Field Study in The Finance Sector. International Journal of Business and Management Studies, 4(2), 31-42. 